\title{
A comparative study of small intestinal perforation secondary to foreign body and other non-traumatic causes
}

\author{
Qiang Chen, M.D., ${ }^{1 *}$ Yuanquan Huang, M.D. ${ }^{2 *}$ Yongyou Wu, M.D., ${ }^{1}$ Kui Zhao, M.D., ${ }^{1}$ \\ Baosong Zhu, M.D., ${ }^{1}$ Tengfei He, M.D., ${ }^{1}$ Chungen Xing, M.D. ${ }^{1}$ \\ 1Department of General Surgery, The Second Affiliated Hospital of Soochow University, Suzhou, Jiangsu, China \\ 2Department of Interventional Radiology, The First People's Hospital of Changzhou, Affiliated Third Hospital of Soochow University, \\ Changzhou, Jiangsu, China \\ ${ }^{*}$ These authors share first authorship.
}

\begin{abstract}
BACKGROUND: Little was known about gastrointestinal perforation secondary to foreign body in adults, which was only documented by several case series reports. The aim of this study was to characterize it with comparative methods.
\end{abstract}

METHODS: A retrospective study was conducted on twenty patients with the diagnosis of gastrointestinal perforation secondary to foreign body between January 2003 and October 2013. The perforations were all located in the small intestine and compared to eighty-seven patients with non-traumatic small intestinal perforation.

RESULTS: $35 \%$ of the patients in the foreign body group were over 65 years of age, which is much higher than the local elderly population ratio $(p=0.002)$. In the foreign body group, more patients presented without diffuse abdominal physical signs $(p=0.008)$ and preoperational CT scans had higher accuracy $(p=0.027)$. Perforation repair was performed more often $(p=0.024)$. Mean MPI was I9.9 and the morbidity rate was $35 \%$, significantly lower than in the cases of other causes $(p=0.00 \mathrm{I}, 0.04 \mathrm{I})$. Mean duration of hospitalization was II .5 days and was shorter compared to other causes $(p=0.038)$.

CONCLUSION: Clinical performance of small intestinal perforation secondary to foreign body is atypical, and preoperative diagnosis relies on CT scans. Primary perforation closure is safe and effective, and relatively better outcomes can be achieved.

Key words: Foreign body; intestinal perforation.

\section{INTRODUCTION}

Ingestion of foreign bodies is more common in children between 6 months and 6 years of age, ${ }^{[1,2]}$ and most foreign bodies can pass the gastrointestinal tract without any complications. ${ }^{[3]}$ However, it can also occur in adult patients and cause severe complications with high morbidity and mortality. [4,5] Although endoscopic intervention is the golden standard treatment for foreign body ingestion, ${ }^{[6]}$ surgical operation is essential for patients with serious complications like gastrointestinal perforation. ${ }^{[7]}$ Adult cases with gastrointestinal perfo-

Address for correspondence: Chungen Xing, M.D.

General Surgery Department, the Second Affiliated Hospital of Soochow University, 1055 Sanxiang Road 215004 Suzhou - China

Tel: 8613776100906 E-mail: bradychen@sohu.com

Qucik Response Code

Ulus Travma Acil Cerrahi Derg

20I5;2I (2): I07-II 2

doi: $10.5505 /$ tjtes.2015.43896

Copyright 2015

TJTES ration after foreign body ingestion have rarely been reported. To the best of our knowledge, there is no comparative study of gastrointestinal perforation yet. The aim of this study was to investigate the clinical characteristics and outcome of adult intestinal perforations after foreign body ingestion by comparing with intestinal perforation of other non-traumatic causes.

\section{MATERIALS AND METHODS}

This retrospective study was conducted in two tertiary hospitals in China, whose study protocol was approved by the Ethical Committees of both hospitals.

The medical records of adult patients, who were over 18 years of age at the time of enrollment and received surgical operation in these two hospitals between January 2003 and October 2013, were retrospectively searched in discharge diagnosis with International Classification of Diseases code 10: K27.I0I, K27.I03, K27.503, K62.8I0, K63.I0I, K63.I03 and K63.I04. Afterwards, the corresponding operation documents were reviewed manually. A total of twenty patients met the diagnosis of gastrointestinal perforation secondary to foreign body, and all the perforation sites were located 
in the small intestine. Therefore, all small intestinal perforation cases of other non-traumatic causes were also included as the control group. Totally, eighty-seven patients were included into the control group.

In this study, decision for surgical operation was based on clinical examination with the aid of plain radiographs or CT scans, which would be performed based on surgeons' assessment and preference. All patients received emergency operations under general anesthesia, and surgical procedure was chosen by the surgeon according to intra-operative findings. All intestinal anastomoses were either hand-sewn or stapled. Prior to abdominal incision closure, peritoneal cavity washout was performed for all patients. After the operation, all patients received empiric antibiotics and fluid resuscitation treatment.

Medical records of all patients, including demographic data, past history of systemic diseases and abdominal surgery operation, initial clinical presentations, accessory examination, therapeutic interventions, complications during hospitalization and outcomes, were reviewed and analyzed. Physical status was classified by American Society of Anesthesiologists (ASA) ${ }^{[8]}$ The severity of abdominal sepsis and post-operative complications were graded with the Mannherm peritonitis index $(\mathrm{MPI})^{[9]}$ and the classification proposed by Clavien and group, ${ }^{[10,11]}$ respectively.
All clinical data was analyzed with the Statistical Package for the Social Science version 20.0 (SPSS, Chicago, IL, USA). Student's $t$ test was used for continuous variables following normal distribution, non-parametric (Mann-Whitney $U$ ) test was used for continuous variables following abnormal distribution or ordinal categorical variables, $\chi^{2}$, Fisher exact test was used for non-ordinal categorical variables when appropriate, and Bivariate test was used to analyze the relationship between MPI and complications. Continuous data following normal and abnormal distribution were presented as mean (SD) and median (range), respectively. Categorical variables data were given as frequencies and percentages. All reported $p$ values were two-sided, and only $p$ values less than 0.05 were considered statistically significant.

\section{RESULTS}

A total of one hundred and seven patients were diagnosed with small intestinal perforation and received surgical operation treatment in our study. Of these cases, twenty (I8.7\%) patients were diagnosed with intestinal perforation secondary to foreign body, and the remaining eighty-seven (8I.3\%) patients were diagnosed with intestinal perforation secondary to other causes, including hernia $(n=30,28.0 \%)$, adhesion $(n=17,15.9 \%)$, Crohn's disease $(n=8,7.5 \%)$, diverticulitis

Table I. Comparison of demographic and clinical characteristics

\begin{tabular}{|c|c|c|c|}
\hline & Foreign body group & Control group & $\mathbf{p}$ \\
\hline \multicolumn{4}{|l|}{ Hospital } \\
\hline 1 & $9(45 \%)$ & 37 (42.5\%) & \\
\hline 2 & II (55\%) & $50(57.5 \%)$ & 0.840 \\
\hline \multicolumn{4}{|l|}{ Gender } \\
\hline Male & $15(75 \%)$ & $62(71.3 \%)$ & \\
\hline Female & $5(25 \%)$ & $25(28.7 \%)$ & 0.737 \\
\hline Age (years) & $59.0 \pm 16.6$ & $59.3 \pm 17.5$ & 0.951 \\
\hline Duration of symptoms (hours) & $24.5(5.0-188.0)$ & $25.0(2.0-280.0)$ & 0.911 \\
\hline \multicolumn{4}{|l|}{ Number of comorbidity } \\
\hline 0 & II (55\%) & $58(66.7 \%)$ & \\
\hline 1 & $6(30 \%)$ & $17(19.5 \%)$ & \\
\hline 2 & $3(15 \%)$ & $7(8.0 \%)$ & \\
\hline 3 & 0 & $4(4.6 \%)$ & \\
\hline 4 & 0 & 0 & \\
\hline 5 & 0 & I (I.I\%) & 0.297 \\
\hline History of abdominal surgical operation & 7 (35\%) & 17 (19.5\%) & 0.147 \\
\hline \multicolumn{4}{|l|}{ ASA classification* } \\
\hline 1 & 7 (35\%) & 31 (35.6\%) & \\
\hline 2 & $9(45 \%)$ & $23(26.4 \%)$ & \\
\hline 3 & $4(20 \%)$ & $26(29.9 \%)$ & \\
\hline 4 & 0 & 7 (8.0\%) & 0.351 \\
\hline
\end{tabular}



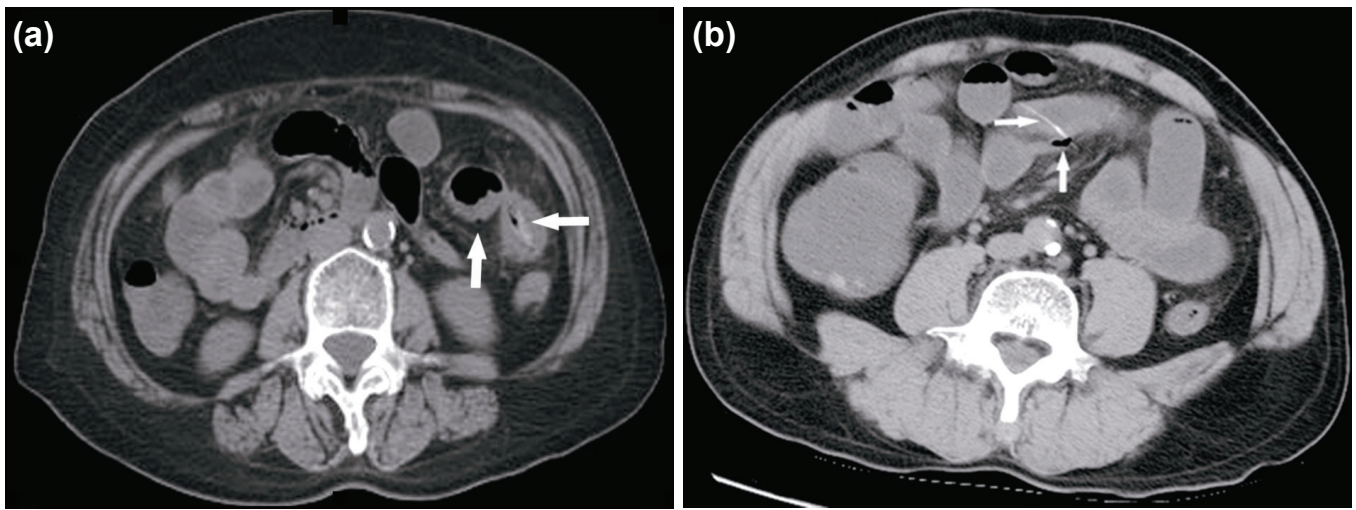

Figure 1. The CT scans show the foreign bodies (a common jujube seed in figure (a) and a fish bone in figure (b)) (horizontal arrow) and small quantity of free peritoneal gas (vertical arrow).

$(n=7,6.5 \%)$, malignancy $(n=6,5.6 \%)$, tuberculosis $(n=2,1.9 \%)$, mesentery vein thrombus $(n=1,0.9 \%)$ and other unclear causes $(n=16,15.0 \%)$.

In this study, $35 \%$ and $42.5 \%$ patients of the foreign body group and control group were over 65 years of age, respectively, which is much higher than the local elderly population ratio of $9.8 \%(p=0.002,0.000$, respectively). Predisposing factors for foreign body ingestion were wearing dentures: $n=13(65 \%)$; allotriophagy: $n=I$ (5\%); and dysgnosia: $n=I(5 \%)$. Except for one case of allotriophagy, all patients hadn't presented with foreign body ingestion history. All were unconscious of having ingested any foreign bodies, except for one case with allotriophagy and one case with dysgnosia. There was no statistically significant difference in demographic data, previous history, and physical status between the two groups (Table I).
Patients of the foreign body group had higher probability of presenting with local abdominal pain with or without peritoneal irritation while diffuse abdominal pain with peritoneal irritation was more often in the cases of other non-traumatic causes. Pre-operative CT scan had higher accuracy in the foreign body group, which showed signs of pneumoperitoneum and foreign body in all seven cases (Figs. Ia, b), with the foreign body of one patient detected retrospectively after operation owing to the low density of the ingested common jujube seed. The differences between the two groups in blood pressure, body temperature, white blood cell count, leucocrit, or plain film results were not statistically significant, as shown in Table 2 .

All patients were diagnosed with small intestinal perforation intra-operatively. Foreign bodies found during operation were fish bones $(n=11,55 \%)$, bone flaps $(n=4,20 \%)$, com-

Table 2. Comparison of auxiliary examination

\begin{tabular}{|c|c|c|c|}
\hline & Foreign body group & Control group & $\mathbf{p}$ \\
\hline \multicolumn{4}{|l|}{ Physical signs } \\
\hline None & $4(20 \%)$ & $7(8.0 \%)$ & \\
\hline Local & $10(50 \%)$ & $26(29.9 \%)$ & \\
\hline Diffuse & $6(30 \%)$ & $54(6.2 \%)$ & 0.008 \\
\hline \multicolumn{4}{|l|}{ Blood pressure (BP) } \\
\hline Systolic BP (mmHg) & $122.9 \pm 14.5$ & $126.4 \pm 21.6$ & 0.490 \\
\hline Diastolic BP (mmHg) & $70.1 \pm 9.3$ & $75.3 \pm 13.8$ & 0.113 \\
\hline White blood cell count (10\%/L) & I $3.0(3.0-22.0)$ & $12.3(1.7-25.6)$ & 0.342 \\
\hline Leucocrit (\%) & $88.1(83.5-95.2)$ & $86.3(67.4-96.7)$ & 0.171 \\
\hline Body temperature $\left({ }^{\circ} \mathrm{C}\right)$ & $37.2(36.1-38.9)$ & $36.9(35.2-39.9)$ & 0.169 \\
\hline \multicolumn{4}{|l|}{ Plain film } \\
\hline Positive & $3(15 \%)$ & 19 (21.8\%) & \\
\hline Negative & $7(35 \%)$ & $28(32.2 \%)$ & 0.725 \\
\hline \multicolumn{4}{|l|}{ CT } \\
\hline Positive & $7(35 \%)$ & $13(14.9 \%)$ & \\
\hline Negative & 0 & $13(14.9 \%)$ & 0.027 \\
\hline
\end{tabular}


Table 3. Comparison of surgical treatments and outcomes

\begin{tabular}{|c|c|c|c|}
\hline & Foreign body group & Control group & $\mathbf{p}$ \\
\hline Duration of surgical operation (min) & $120.0 \pm 67.4$ & $132.6 \pm 65 . \mid$ & 0.445 \\
\hline \multicolumn{4}{|l|}{ Location of perforation } \\
\hline Jejunum & $3(15 \%)$ & $24(27.6 \%)$ & \\
\hline Ilium & 17 (85\%) & $63(72.4 \%)$ & 0.275 \\
\hline Mannherm peritonitis index (MPI) & $19.9 \pm 6.6$ & $26.2 \pm 8.4$ & 0.001 \\
\hline \multicolumn{4}{|l|}{ Surgical operation type } \\
\hline Repair & $16(80 \%)$ & $36(4 \mid .4 \%)$ & \\
\hline Resection & $3(15 \%)$ & $37(42.5 \%)$ & \\
\hline Right hemicolectomy & I (5\%) & $10(11.5 \%)$ & \\
\hline Stoma & 0 & $4(4.6 \%)$ & 0.024 \\
\hline \multicolumn{4}{|l|}{ Classification of complications } \\
\hline Grade I & I (5\%) & 0 & \\
\hline Grade II & $4(20 \%)$ & $24(27.6 \%)$ & \\
\hline Grade III & I (5\%) & $4(4.6 \%)$ & \\
\hline Grade IV & $\mathrm{I}(5 \%)$ & $9(10.3 \%)$ & \\
\hline Grade V & 0 & II (I2.6\%) & 0.042 \\
\hline Hospital stay of survivors (days) & II.5 (7.0-14.0) & $14.0(7.0-56.0)$ & 0.038 \\
\hline
\end{tabular}

mon jujube seeds $(n=2,10 \%)$, metal threads $(n=2,10 \%)$, and toothpick $(n=I, 5 \%)$. Comparison of surgical treatments and outcomes in both groups during hospitalization is shown in Table 3. The duration of surgical operation in the foreign body group was shorter than in the control group, but it was not statistically different. lleum was involved more often than jejunum in both groups. MPI was associated with prognosis and complication $(p=0.00)$ and mean MPI was significantly lower in the foreign body group. During surgical operation, perforation repair was performed more often in the foreign body group while partial intestinal resection, stoma or right hemicolectomy were done more often in the control group. There was no death case in the foreign body group while the mortality rate was $12.6 \%$ in the control group, and the morbidity rate of the foreign body group and control group was $35 \%$ and $55.2 \%$, respectively. Accordingly, the duration of hospitalization was shorter in the foreign body group than in the control group.

In this study, no statistical significance could be found in any study items between the patient groups from two hospitals.

\section{DISCUSSION}

As previous case series have reported, the groups with increased risk of ingesting foreign bodies include children and adolescents, the elderly, psychiatric patients, drug addicts, and alcoholics. Oral problems, wearing denture, improper mastication and poor vision are predisposing factors of foreign body ingestion. ${ }^{[12]}$ The majority of our patients were the elderly, and $35 \%$ of the patients in the foreign body group were over 65 years of age. Wearing dentures was the most common predisposing factor since the presence of dentures impaired the tactile sensitivity of the palate, resulting in unconscious ingesting of foreign bodies. ${ }^{[13]}$ Previous abdominal operation history might increase the risk of gastrointestinal perforation after foreign body ingestion since $35 \%$ of the patients in the foreign body group had history of such surgical operation, and foreign body is easy to impact narrow, angled, pouching areas, and zones with adhesions or surgical anastomosis. ${ }^{[5]}$

Most ingested foreign bodies can pass through the gastrointestinal tract successfully without any complications, with only about $1 \%$ of the foreign bodies perforating the intestinal wall. However, if the foreign body is a sharp object, the possibility mounts up to $35 \% .{ }^{[14]}$ In up to $93 \%$ of the cases, foreign bodies are component parts of ordinary diet. ${ }^{[15]}$ In our group, all foreign bodies were sharp objects, and in seventeen cases (85\%), they belonged to ordinary diet. Although perforation can take place all over the alimentary tract, the ileocaecal region is the most common area. ${ }^{[15]}$ In our study, all patients had small intestinal perforation, and most of the perforation sites (17/20) were located in distal ileum within $2 \mathrm{~m}$ to the ileocaecal valve.

The perforation process caused by progressive impaction of the foreign body is usually slow, allowing perforation site to be covered by fibrin and adjacent loops and prevents the leakage of extensive quantities of fluid or gas. ${ }^{[16]}$ As a result, the occult symptoms varying from abdomen pain to local or diffuse peritonitis, along with the lack of awareness of having 
ingested any foreign bodies, make preoperative diagnosis difficult. ${ }^{[13]}$ Clinically common denominator is acute abdominal pain accompanied by severe inflammatory laboratory tests (severe elevation of the white blood cell count and C-reactive protein level). ${ }^{[17]}$ In our study, there was no significant difference between the two groups on vital signs and laboratory tests. However, more patients in the foreign body group presented with slight symptoms and physical signs, and the group hadn't presented with foreign body ingestion history, except for one case of allotriophagy. As a result, five cases were misdiagnosed as having acute appendicitis pre-operatively. Exposure was very difficult 3 of the cases because the perforation site was far away from the incision.

Since the leakage of intestinal contents and gas is usually in small amounts and spontaneous closure of the defect and rapid resorption of any free gas can occur between the occurrence of the perforation and subsequent radiologic examination, pneumoperitoneum is seen in less than $50 \%$ of the patients in abdominal plain film. ${ }^{[18]}$ Radiographs might only show the signs of small intestinal obstruction and could not identify the foreign body unless it is sufficiently radiopaque. Although chicken or fish bones may be sufficiently radiopaque to be found on abdominal plain film, large amount of soft tissue or fluid may obscure their minimal calcium contents, particularly in obese patients. ${ }^{[19]}$ The sensitivity of plain film was low in both groups in our study. In the foreign body group, of the twelve cases who received plain film radiography examination, only four (33.3\%) patients showed signs of pneumoperitoneum, and only the metallic foreign bodies could be found in one allotriophagy patient.

CT scan can detect the calcified content of ingested foreign body, the presence of very small quantity of extra-luminal gas and associated complications, like abscess and obstruction. On the other hand, CT scan can eliminate other possible causes of acute abdominal conditions. ${ }^{[20]}$ Thanks to the increasing availability of multidetector-row CT and spiral CT, high quality multiplanar reconstructions can be obtained with a very short delay, and foreign bodies are found without the restriction by their orientation. ${ }^{[17]}$ More and more emergency patients with various non-traumatic acute abdominal conditions receive $C T$ scans, which can characterize the aetiology of their abdominal pain and has the greatest impact on hospital admissions and surgical management. ${ }^{[21]}$ In our group, preoperative CT scan was performed in seven patients, all of whom showed signs of pneumoperitoneum and foreign bodies in plain scans and associated reconstructions. Interestingly, preoperative CT scan had higher sensitivity in the foreign body group than in the control group, and the reason might be associated with the existence of foreign body that attracted the attention of the image readers. Therefore, we propose that plain scans and associated reconstructions, which are cost-effective and easy to obtain, are enough in such emergency situations.

Preoperative diagnosis of intestinal perforation after foreign body ingestion relies on photography examination. Recent technical developments have led to the wide usage and elevated accuracy of CT scans. Nevertheless, definitive diagnosis is usually reached during exploratory laparotomy for most patients. ${ }^{[22]}$ Surgical treatment is tailored to the individual patient. If conditions permit, laparoscopic repair can be attempted. ${ }^{[23]}$ Surgical principles for intestinal perforation include early containment of the contamination, copious lavage, and partial resection for diseased segment removal and pathological examination. ${ }^{[24]}$ In the foreign body group, more perforation closure operations were performed because of higher portion of small perforations and lower abdominal contamination. Another important reason was that the etiology of perforation could be confirmed during operation, and there was no need to perform partial intestinal resection for pathological examination.

Although medical treatment has improved greatly since more than half a century, the mortality rate of small intestinal perforation is still as high as about $19.1 \% .{ }^{[24]}$ Postoperative mortality attributed to intestinal perforation after foreign body ingestion is $6.1-6.5 \%$, and morbidity is $24.2-57.6 \% .^{[5,15]}$ Some of the factors associated with poorer outcomes include worse peritoneal contamination and significant physiological derangement. ${ }^{[24]}$ The morbidity of our foreign body group was comparable to other series at $35 \%$. Though it was still considerable, most of the cases (7I.4\%) had mild complications. Apart from morbidity, there was no dead or anastomosis leakage cases in the foreign body group. MPI can predict the outcome of patients according to the severity of the peritonitis as the patients with higher MPI scores were associated with worse perioperative outcome. ${ }^{[2]}$ In our study, MPI scores was associated with prognosis and complication. The control group had higher MPI scores, and accordingly, had higher mortality, morbidity rates and longer duration of hospitalization. The reason of this phenomenon might be that the greater diameter of perforation and pre-existing complications before perforation, like intestinal and infection, caused worse peritoneal contamination and more significant physiological derangement in the control group.

Like perforation of other non-traumatic causes, small intestinal perforation secondary to foreign body was more common in the elderly population and involved ileum more often. It was difficult to diagnose pre-operatively without the history of foreign body ingestion, typical symptom or physical signs. Plain CT scan and associated reconstruction had high accuracy to make the diagnosis and locate the foreign bodies. It was proper and safe to repair by primary suture after foreign body removal. As compared with small intestinal perforation of other non-traumatic causes, the patients with small intestinal perforation after foreign body ingestion had relatively lower MPI scores, and consequently had lower mortality, morbidity, and shorter hospital stay after operation.

Acknowledgment: This study was sponsored by the Science, Education and Health Foundation of Soochow City KJXW2012016 and 201017. 
Conflict of interest: None declared.

\section{REFERENCES}

1. Cheng W, Tam PK. Foreign-body ingestion in children: experience with 1,265 cases. J Pediatr Surg 1999;34:1472-6.

2. Hachimi-Idrissi S, Corne L, Vandenplas Y. Management of ingested foreign bodies in childhood: our experience and review of the literature. Eur J Emerg Med 1998;5:319-23.

3. Nandi P, Ong GB. Foreign body in the oesophagus: review of 2394 cases. Br J Surg 1978;65:5-9.

4. Syrakos T, Zacharakis E, Antonitsis P, Zacharakis E, Spanos C, Georgantis $\mathrm{G}$, et al. Surgical intervention for gastrointestinal foreign bodies in adults: a case series. Med Princ Pract 2008;17:276-9.

5. Rodríguez-Hermosa JI, Codina-Cazador A, Sirvent JM, Martín A, Gironès J, Garsot E. Surgically treated perforations of the gastrointestinal tract caused by ingested foreign bodies. Colorectal Dis 2008;10:701-7.

6. Mosca S, Manes G, Martino R, Amitrano L, Bottino V, Bove A, et al. Endoscopic management of foreign bodies in the upper gastrointestinal tract: report on a series of 414 adult patients. Endoscopy 2001;33:692-6.

7. Toyonaga T, Shinohara M, Miyatake E, Ouchida K, Shirota T, Ogawa T, et al. Penetration of the duodenum by an ingested needle with migration to the pancreas: report of a case. Surg Today 2001;31:68-71.

8. Keats AS. The ASA classification of physical status--a recapitulation. Anesthesiology 1978;49:233-6.

9. Billing A, Fröhlich D, Schildberg FW. Prediction of outcome using the Mannheim peritonitis index in 2003 patients. Peritonitis Study Group. Br J Surg 1994;81:209-13.

10. Clavien PA, Sanabria JR, Mentha G, Borst F, Buhler L, Roche B, et al. Recent results of elective open cholecystectomy in a North American and a European center. Comparison of complications and risk factors. Ann Surg 1992;216:618-26.

11. Dindo D, Demartines N, Clavien PA. Classification of surgical complications: a new proposal with evaluation in a cohort of 6336 patients and results of a survey. Ann Surg 2004;240:205-13.
12. Furukawa A, Sakoda M, Yamasaki M, Kono N, Tanaka T, Nitta N, et al. Gastrointestinal tract perforation: CT diagnosis of presence, site, and cause. Abdom Imaging 2005;30:524-34.

13. Maleki M, Evans WE. Foreign-body perforation of the intestinal tract. Report of 12 cases and review of the literature. Arch Surg 1970;101:474-7.

14. Ohri SK, Hutton KA, Walsh R, Desa LA, Wood CB. Foreign body perforation of the ileum. Br J Clin Pract 1990;44:647-8.

15. Goh BK, Chow PK, Quah HM, Ong HS, Eu KW, Ooi LL, et al. Perforation of the gastrointestinal tract secondary to ingestion of foreign bodies. World J Surg 2006;30:372-7.

16. Madrona AP, Fernandez-Hernandez JA, Carasco M, Carasco Pratas M, Riquelme J, Paritta Paricio P. Intestinal perforation by foreign bodies. Eur J Surg 2000;166:307-9.

17. Coulier B, Tancredi MH, Ramboux A. Spiral CT and multidetector-row CT diagnosis of perforation of the small intestine caused by ingested foreign bodies. Eur Radiol 2004;14:1918-25.

18. Ghahremani GG. Radiologic evaluation of suspected gastrointestinal perforations. Radiol Clin North Am 1993;31:1219-34.

19. Maglinte DDT, Taylor SD, Ng AC. Gastrointestinal perforation by chicken bones. Radiology 1979;130:597-9.

20. Coulier B. Diagnostic ultrasonography of perforating foreign bodies of the digestive tract. [Article in French] J Belge Radiol 1997;80:1-5. [Abstract]

21. Rosen MP, Siewert B, Sands DZ, Bromberg R, Edlow J, Raptopoulos V. Value of abdominal CT in the emergency department for patients with abdominal pain. Eur Radiol 2003;13:418-24.

22. Syrakos T, Zacharakis E, Antonitsis P, Zacharakis E, Spanos C, Georgantis $\mathrm{G}$, et al. Surgical intervention for gastrointestinal foreign bodies in adults: a case series. Med Princ Pract 2008;17:276-9.

23. Wichmann MW, Huttl TP, Billing A, Jauch KW. Laparoscopic management of a small bowel perforation caused by a toothpick. Surg Endosc 2004; $18: 717-8$

24. Tan KK, Bang SL, Sim R. Surgery for small bowel perforation in an Asian population: predictors of morbidity and mortality. J Gastrointest Surg 2010;14:493-9.

\section{KLINIK ÇALIŞMA - ÖZET}

\section{Yabancı cisimle ince bağırsak perforasyonu ile diğer travma dışı nedenlerin karşılaştırmalı çalışması \\ Dr. Qiang Chen, ${ }^{1}$ Dr. Yuanquan Huang, ${ }^{2}$ Dr. Yongyou Wu, ${ }^{1}$ Dr. Kui Zhao, ${ }^{1}$ Dr. Baosong Zhu, ${ }^{1}$ Dr. Tengfei He, ${ }^{1}$ Dr. Chungen Xing ${ }^{1}$}

${ }^{1}$ Soochow Üniversitesi, İkinci Bağı Hastanesi, Genel Cerrahi Kliniği, Suzhou, Jiangsu, Çin

${ }^{2}$ Soochow Üniversitesi, Üçüncü Bağıı Hastanesi, Changzhou İlk Halk Hastanesi, Girişimsel Radyoloji Bölümü, Changzhou, Jiangsu, Çin

AMAÇ: Yetişkinlerde yabancı cisme bağıı gastrointestinal perforasyon hakkında çok az bilgi sahibi olunduğu gibi, yalnızca birkaç olgu çalışmasında gastrointestinal perforasyon belgelenmiştir. Bu çalışmanın amacı bu olgularda karşılaştırmalı yöntemleri sunmaktır.

GEREÇ VE YÖNTEM: Ocak 2003 ile Ekim 2013 tarihleri arasında yabancı cisimle gastrointestinal perforasyon tanısı konmuş 20 hastada geriye dönük bir çalışma yürütüldü. Bu hastaların hepsinde perforasyonlar ince bağırsak yerleşimliydi ve bu hastalar travma dışı nedenlere bağlı ince bağırsak perforasyonu olmuş 87 hasta ile karşılaştırıldı.

BULGULAR: Yabancı cisim grubundaki hastaların \%35'i, yerel popülasyona göre çok daha yaşlı olup 65 yaşın üstündeydi ( $p=0.002$ ). Yabancı cisim grubunda daha fazla sayıda hastada yaygın abdominal fiziksel bulgu olmadığı gibi $(p=0.008)$ ve ameliyat öncesi bilgisayarlı tomografi taramaları daha büyük bir doğruluk derecesine sahipti $(p=0.027)$. Daha büyük bir sıklıkla perforasyon onarımı yapılmıştı $(p=0.024)$. Ortalama MPI I9.9 ve morbidite oranı \%35 olup diğer nedenlere bağlı olgulara göre anlamlı derecede daha düşük idi $(p=0.001$ ve 0.04 I). Diğer nedenlere bağlı perforasyonlara göre hastanede yatış süresi daha kısaydı $(p=0.038)$.

TARTIŞMA: Yabancı cisme bağlı ince bağırsak perforasyonun klinik sunumu atipik olup ameliyat öncesi tanı bilgisayarlı tomografı taramalara bağlıdır. Birincil perforasyonun kapanması güvenli ve etkili olup göreceli olarak daha iyi sonuçlar elde edilebilir.

Anahtar sözcükler: Bağırsak perforasyonu; yabancı cisim.

Ulus Travma Acil Cerrahi Derg 2015;2I(2): I07-II2 doi: 10.5505/tjtes.20I5.43896 